LETTERS TO THE EDITOR.

[The Editor does not hold himself responsible for opinions expressed by his correspondents. Neither ian he undertake to return, or to correspond with the writers of, rejerted manuscripts intended for this or any other part of NATURE. No notice is taken of anonymous communications.]

\section{The Food of the Rook.}

Is there not even a fallacy in the argument against this bird which is supported by a note in NATURE of June 6, p. 27I? You say that because 52 per cent. of the rook's food is injurious, 19.5 per cent. neutral, and 28.5 per cent. beneficial, therefore "it is impossible to ignore the fact that at present this bird does considerably more harm than good," even though, as you admit, 23.9 per cent. of the rook's food consists of injurious insects.

Is it not possible that if these injurious insectsthey doubtless consist of many species--had been left unconsumed by the rook, they might have so multiplied that their total depredation upon man's food supply would have considerably exceeded the 52 per cent. of foodstuffs which the bird consumes directly?

As a method more likely to restore the balance of Nature than the indiscriminate destruction of certain species of birds, the rook included, I would suggest a strict preservation of all our birds of prey; and now that game-preservation has to take second place to food production, this would seem to be a matter for practical legislation.

Norwich, June Io. SYDNEY H. LONG.

If Dr. Long assumes that the 239 per cent of injurious insects left unconsumed might have multiplied, it is surely only fair that he should also assume that, under similar conditions, the 48.5 per cent, of cereals, potatoes, and roots would have multiplied and brought forth a hundredfold. The point at issue, however, is whether, in estimating by the volumetric method the amount of food consumed by the rook per annum the figures express equivalent or economic values. This method has so long been recognised as the only trustworthy one that it is not necessary to reassert its superiority over all others; and as McAtee has so pertinently remarked (The Auk, I912, p. 452), such "criticisms are wide of the mark, for no one claims that percentages do express economic values. They are simply convenient handles to facts, and they must be interpreted." As the result of long experience and the examination of the alimentary system of upwards of two thousand rooks, by which we have obtained the percentages referred to, viz. that of the food consumed by the rook during a whole vear, 52 per cent. is injurious, 19.5 per cent. neutral, and 28.5 per cent. beneficial, our interpretation of these figures, in the light of a long experience as to the detailed nature of the food under each heading, leads us to the conclusion that this bird does considerably more harm than good.

The advisability of practical- leģislation for the strict preservation of birds of prev and the relationship of such to game-bird preservation is a very complicated subject. All statistics, however, go to prove that the preservation of game-birds is beneficial rather than inimical to food production, and there are many other sides of the auestion which Dr. Long does not seem to have considered. THE Writer of the Note.

A Proof that any Aggregate can be Well-ordered.

Ix my letter printed in NATURE for April 4, rgis (vol. ci., p. 84), the class of direct continuations used for well-ordering should have been stated to be "comNO. 2538 , VOL. IOI] plete"-that is to say, no chain of $M$ outside the class is such that every member of this class is a segment of this new chain. The actual construction of a complete class of direct continuations can be carried out in a perfectly unique manner throughout in terms of the possible chains of $M$, without assuming that there is any chain of $M$ that exhausts $M$ itself. This construction is given in detail in a paper which will shortly appear in the Comptes rendus, and the detail of the consequences of the existence thus proved has already appeared in the Comptes rendus for April 2.

The Bourne, Basingbourne Road, Fleet, Hants, May 3I.

\section{Construction for an Approximate Quadrature of the Gircle.}

THE construction for squaring the circle given by Mr. R. E. Baynes in Nature for June 6 was described more fully by Mr. T. M. P. Hughes in the issue for April 2, I9:14, with a simple extension to the representation of the circumference.

Mr. Hughes suggested the use of a permanent setsquare of the proper angle, and it seems that the method was known earlier, for in the Science Museum at South Kensington I have seen a set-square for the purpose. I did not examine it carefully, but I believe it bore the inscription "Edward Bing, Riga, 1876." Perhaps someone else may know the history of this instrument and method.

University of Edinburgh, June 8.

There are in the Science Museum three examples of the set-square to which Mr. Smeal refers. They have been here since 1876 , in which year they were lent by the inventor, Edward Bing, a member of the staff of the Waggon Works at Riga, for exhibition in the Special Loan Collection of Scientific Apparatus. There is a short description in the third edition of the catalogue of that collection, published in $\mathrm{I} 876$, at $\mathrm{p}$. I4, and $\mathrm{I}$ have no record of any earlier published description. One of the examples is of steel and the other two of wood, the hypotenuse in each case being about $7 \frac{3}{8}$ in. long. The inventor's MS. label inside the mahogany case containing the steel set-square reads:- "Bing's Circular Square. Kreiswinkel. Equerre circulaire. Cosinus $\alpha=\sqrt{\pi / 4}$ $\left(\alpha=27^{\prime} 35^{\prime} 49^{\circ} 636^{\prime \prime}\right)$."

The Science Museum,

South Kensington, June I3. $_{3}$.

\section{INTER-ALLIED SCIENTIFIC FOOD COMMISSION.}

$\mathrm{IN}$ a recent speech $\mathrm{Mr}$. Clynes stated that the events of the last two years had revealed the necessity, not only of securing complete unity of action among the Allies, but also of basing any such action on the guiding principles laid down by science. This reoognition of the fundamental part which science should play in the successful direction of public affairs is noteworthy as coming from a member of the youngest of our political parties, and augurs well for the future of the country when this party comes to be entrusted with a responsibility commensurate with its political power. In fact, much of the success of the Ministry with which Mr. Clynes is connected may be ascribed to the adoption by Lord Rhondda of a policy based on the collective experience of 
scientific men rather than on the political exigencies of the moment. Thus the United Kingdom, alone among the European Allies, has been able to maintain a distribution of bread free from any restriction, at a time when all the others felt themselves constrained to limit the consumption of this, the most essential of all foods, by a system of rationing. This policy does not mean, as is so often thought, that the shortage of breadstuffs in this country was less than that of the other Allies. But Lord Rhondda adopted the scientific policy of economising cereals at the expense of animals, instead of the more obvious expedient of diminishing directly the supply of bread to man.

When the pooling of supplies was decided upon by the Allies meeting in conference, a satisfactory distribution was found practically impossible in the absence of precise knowledge both as to the resources and as to the needs of each nation. The needs of a country depend on physiological facts, and can be deduced from a knowledge of the nutritional requirements of its inhabitants of varying age and sex, and the distribution of these classes of individuals among the population. The question is, therefore, fundamentally a physiological one. The resources of a country can be gathered from the statistical information at the disposal of the Government with regard to agricultural production and trade returns, etc., but the value of these resources as human food is also a question which can be determined only by physiologists. On this account, the Inter-Allied Congress, sitting at Versailles in the autumn of I9I7, decided to establish an Inter-Allied Scientific Food Commission, consisting of two representatives of each of the Allied countries, France, Italy, the United Kingdom, and the United States, which should perform towards the Allies as a whole somewhat similar functions to those which had been discharged for the United Kingdom by the Food Committee of the Royal Society. The task of this Commission was, therefore, to examine the resources of each of the Allied countries, to make a forecast of their production for the year rgr8-19, and to report on the imports which should be allotted to each country in order that it should be supplied with sufficient food to maintain its population in health and efficiency.

The Commission has held three meetings-at Paris, Rome, and London. In the first two meetings the Commission was mainly employed in establishing certain principles which should serve as a basis for its recommendations as to the imports necessary to meet the deficit of each country. It was of importance in the first place that all countries should make use of the same units of measurement, and base their calculations of food values on the same sets of figures for calorie value and composition of the chief foodstuffs. Thus it was agreed to use the metric ton as the unit of weight, the hectare as the unit of area. A list of the average calorie values of foods, based chiefly on the results of Atwater, was drawn up NO. 2538 , VOL. IOI] for use by all Allied countries. As regards the food requirements of the ' average man,' and the relation thereto of women and children of various ages, the Commission accepted the figures given by Lusk. Uniform milling values were arranged, and all countries accepted the principle that the maximum possible amount of cereals, with the exception of oats, should be assigned to human food. It was also agreed that, whereas it is impossible to fix any minimum requirement for meat, it is desirable that the ration of fat should at no time fall below 75 grams per 'average man per day. The question of a minimum protein ration presented no difficulty, since a sufficient amount of this foodstuff is contained in a mixed diet of adequate calorie value. The Commission thus accepted Bayliss's dictum : "Take care of the calories and the protein will take care of itself." The Commission also laid down the form in which the statistics of production in pre-war years and the forecast of production in the coming year should be presented by each delegation from information supplied by its Government.

We understand that the examination of these balance-sheets for each country has been the work of the Commission during its meeting in London, which has just terminated, and that the Commission will shortly present to the Allied Governments for the use of the Inter-Allied Executives, on whom devolves the task of procuring and apportioning the foods available for import from abroad, a report in which is laid down the relative share in these imports due to each Allied country. It must not be imagined, however, that it is the office of such a scientific commission to effect a rigorous subdivision of the hundredand-one articles which may enter the Allied countries as food. All it can do is to indicate the principles of such a division and the limits within which it must be carried out. The total food to be imported will be given by the number of food calories due to each country. Some indication as to the distribution of these calories among staple foods, such as meat and cereals, is afforded by the agreement that 75 grams of fat per day should be provided in each country for every ' average man.' In this way a rough subdivision of imports is achieved, but the final division must be left to the Executives, who will be guided by the three controlling factors, viz. supplies, tonnage, and finance.

But this, after all, is the proper limitation of the function of science in public affairs. Science should be the eyes, the informative organ of the State, rather than the organ of volition. The responsibility of action lies with the administration, but the success of the measures adopted will be in direct proportion to the degree in which they are based on the broad principles taught by the body of human experience, which is science.

The members of the Inter-Allied Scientific Food Commission are as follows:-France, Profs. Gley and Langlois; Italy, Profs. Bottazzi and Pagliani; Belgium, Prof. Rulot; United States, Profs. Chitten- 
den and Lusk; United Kingdom, Profs. E. H. Starling and T. B. Wood. The conclusions agreed upon by the Commission are summarised in the following paragraphs :-

(I) The Commission has decided to state the weights of the various foods produced in each Allied country in metric tons.

(2) The Commission has decided that it is not desirable to fix a minimum meat ration in view of the fact that no absolute physiological need exists for meat, since the proteins of meat can be replaced by proteins of animal origin, such as those contained in milk, cheese, and eggs, as well as by proteins of vegetable origin. The Commission, on the other hand, resolved to fix a desirable minimum ration of fat. This desirable minimum ration amounts to 75 grams per average man per day. The ration will be made up of (i) fats of vegetable origin and (ii) fats of animal origin. If the amount of fats of vegetable origin is insufficient for this purpose, it may be necessary to maintain a certain stock of animals to furnish a sufficient quantity.

(3) The Commission has established the "man value," i.e. the number of average men equivalent to the population of each of the Allied countries. This man value is taken as the basis for calculating the exact amount of food which must be provided for the adequate nourishment of the total population of each country.

(4) The Commission has considered estimates in tons of the home productions of the soil furnished by each Allied country for the year 1918-10. These statistics will serve as a basis for determining the amount of food available for men and for animals respectively in each country.

(5) The Commission recommends that each delegation, in calculating the amount of calories available for men, should assign to men the maximum possible proportion of all cereals except oats.

(6) The Commission is of opinion that a uniform average milling extraction of 85 per cent. for wheat be adopted throughout the Allied countries. It is recognised that this extraction may vary from 80 per cent. in summer to go per cent. in winter, and that it can apply to the United States only as regards their internal consumption, and then only in case of scarcitv.

(7) The Commission recognises that the methods adopted for reserving the maximum possible proportion of the cereal production for the use of man may vary in each country. Man should always take precedence over animals in the allocation of food by the Governments. If this principle be accepted, the Commission is of opinion that in the fixing of prices it is the prices of animal products which should be limited rather than those of such vegetable products of the soil as may serve equally well for feeding men and animals.

Thus the production of veal, pork, and poultry at the expense of food available for man should be discouraged, and this is best achieved by fixing a price for those animal products which will make it unprofitable for the oroducer to feed the animals on cereals.

(8) The Commission reserves for its next meeting the task of examining the figures which will enable it th determine the calorie value of the home production of each of the Allied countries during the year rorS-10. The determination of this fioure comparer with the needs in calories of the population of each country will enable the Commission to deduce either the amount of imports necessary for the maintenance of the population or the exportable surplus, as the case may be.

(a) The Commission is of opinion that in all the Allied countries any propaganda having for its object the encouragement of food nroduction and of economv in the use of food should be organised and directed by men of science well acquainted with these subjects.

NO. 2538 , VOL. IOI]

\section{THE NEW STAR IN AQUILA.}

CONTINUED observations appear to indicate that the new star in Aquila is following the normal course of such objects, as exemplified especially by Nova Persei (I9OI) and Nova Geminorum (1912). The increase of brightness from about magnitude 0.9 at the time of discovery on June 8 to a brightness equal to, or greater than, that of Vega (o.r. m.) on June 9 was succeeded by a steady decline, so that on June $x 6$ the star was reduced to about second magnitude. Nova Persei showed a closely similar rate of fading, from near magnitude o on February 23 to magnitude 2 on March 2, and if this precedent be followed, Nova Aquilæ may be expected to reach the third magnitude about June $2 x$, and the fourth magnitude about ten days later. Small oscillations, however, may possibly accompany the general decline.

The spectrum of the nova also appears to have followed the expected sequence of changes, so far as can be gathered from the brief reports presented at the meeting of the Royal Astronomical Society on June 14 by the Astronomer Royal, Mr. Harold Thomson, and Prof. Fowler on the visible spectrum, and by Prof. Newall, Father Cortie, and the Rev. T: E. R. Phillips on the photographic spectrum. The spectroscopic observations may be conveniently summarised by comparison with previous novæ, as discussed by Sir Norman Lockyer in a memoir on the phenomena of new stars published by the Solar Physics Committee in I9I4. It is there shown that there are four distinct stages in the history of a nova as revealed by its spectrum: (x). A stage of short duration in which the spectrum is continuous, or continuous with dark lines, occurring during the rise to maximum brightness. (2) The bright-line, or "typical nova," stage, where the outstanding feature is a spectrum crossed by broad bright bands, many of which are accompanied by absorption bands on their more refrangible edges; the brightest lines are those of hydrogen, but enhanced lines of iron are also prominent. (3) A stage marked by the presence of a bright band of unknown origin about $\lambda 4640$, which is sometimes the brightest in the whole spectrum. (4) The nebular stage, characterised by the bright lines of gaseous nebulæ, of which 5007 and 4959 are the brightest in the visible spectrum.

The first stage was shown in Nova Aquilæ by observations immediately after the discovery, and in observations by Prof. Newall and Mr. Thomson on June 9. It is especially fortunate that the latter part of this transient stage was caught by Father Cortie in a photograph taken at Stonyhurst on June ro, in which dark lines, somewhat resembling those of Procyon, are the chief feature in the blue and violet parts of the spectrum, although bright lines in the visible spectrum were noted on the same evening by other observers.

The second, or "typical nova," stage had become well developed by June II, as shown by 